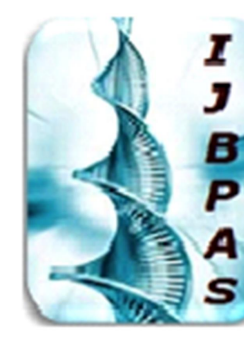

International Journal of Biology, Pharmacy and Allied Seiences (IJBPAS)

'A Bridge Betuen Caboratory and QRendo'

Www.ibpas.com

\title{
STUDY OF ESTIMATION OF URINARY CYSTATIN -C FOR CORRELATION OF RENAL MANIFESTATIONSWITH THE IMMUNOLOGICAL STATUS OF HIV PATIENTS
}

\section{KOLAPARTHI LS ${ }^{1}$, CHAUDHARY GA ${ }^{2}$ AND NETHULA SS ${ }^{3 *}$}

1: $3^{\text {rd }}$ year PG Resident, Department of General Medicine, Dr. D Y Patil Medical College, Hospital \& Research Centre, Pimpri, Pune, India -411018

2: Assistant Professor, Department of General Medicine, Dr. D Y Patil Medical College, Hospital \& Research Centre, Pimpri, Pune, India -411018

3: $2^{\text {nd }}$ year PG Resident, Department of General Medicine, Dr. D Y Patil Medical College,

Hospital \& Research Centre, Pimpri, Pune, India -411018

*Corresponding Author: Dr. Sai Sanketh Nethula: $\underline{\text { sanketh77@gmail.com }}$

Received $15^{\text {th }}$ July 2021; Revised $18^{\text {th }}$ Aug. 2021; Accepted $29^{\text {th }}$ Oct. 2021; Available online $15^{\text {th }}$ Feb. 2022

https://doi.org/10.31032/IJBPAS/2022/11.2.1046

ABSTRACT

Aim: To study the clinical manifestation of renal involvement of HIV patients and its correlation with virologic load and CD4 T- cell count, with correlation with cystatin $-\mathrm{c}$ as early biomarker of renal involvement in HIV patients.

Methodology: Sample of 75 known retro-positive cases who attended Dr DY Patil medical college and hospital, DY Patil Vidyapeeth, Pimpri, Pune during the study period were selected. All procedures and interventions have been established only after obtaining adequate / appropriate consent in a prescribed form. Ethical clearance has been obtained from the Ethical clearance committee in a prescribed certificate.

Results: The spectrum of HIVAN manifests ions are equally distributed among male and female population. dipstick proteinuria is the most effective measure for screening of the patients for renal manifestations in patients with HIV. the significant proteinuria with $>1+$ on dipstick examination in patient with all other causes excluded (hypertension, diabetes mellitus) should always warrant for further investigation. 24 hour urinary and $>3 \mathrm{gm} / \mathrm{dl}$ spot 
Upcr $>3.5 \mathrm{gm} / \mathrm{dl}$ were more associated with HIVAN. Duration of ART doesn't have any correlation with the renal disease or proteinuria if patient maintains good immunological status (CD4+-T -cells $>500 /$ microL) with good adherence to the HAART. The low CD4+T cells is associated with the early onset of renal manifestation with most values below $<200$ cells /microL , and poor adherence or lack of use of HAART , as studies have revealed that the HIV virus stimulates the PODOCYTES to differentiate and podocytopathy is the hallmark of HIVAN and cause of proteinuria.

Conclusion: Hence urinary cystatin -c which is marker of tubular dysfunction is early marker of renal disease in HIVAN patients even before theonset of nephrotic proteinuria.

\section{Keywords: HIV, Cystatin, HAART, CD+4, Podocytopathy, ART}

\section{INTRODUCTION}

HIV infection is a global pandemic with estimated 36.7 million cases globally as per UNAIDS (united nation programme for HIV/AIDS, in $201695 \%$ cases reside in low income countries, with $50 \%$ belonging to children $<15$ years and females combined $^{1}$. AIDS was recognized first in USA in 1981 with AIDS defining complexes, 2 years later in 1983, HIV virus was isolated from a patient with lymphadenopathy. ${ }^{2}$

In 1985, ELISA test was developed which allowed massive screening programme and defining the HIV epidemic .IN 2016 ALONE 1.8 million new cases of HIV infection were detected globally, with majority of cases concentrated in high risk population like sex workers and their clients, I.V drug users, transgender people, and gay men.

There is over all globally increased prevalence In PLHA (people living with
HIV and AIDS) and is due to increase in life span with global increase is availability and utilization of HAART (highly active antiretroviral therapy).

Among all the world counties east and south Africa regions are the hardest hit with about $50 \%$ cases concentrated in this area. In Asia pacific itself the population distribution is very skewed; hence more than $50 \%$ cases are concentrated in three most populous countries of the world china, India and Indonesia ${ }^{3}$

Between 2000-2016 there is 40\% decline in new infection across world -clearly due to HIV prevention programme and increased provision of HAART - which decreases viral load and makes them less likely to transmit the virus to their sexual partner ${ }^{4}$

\section{BURDEN OF HIV IN INDIA:}

The first case of HIV was detected in Chennai in 1986, among female sex workers, as per 2015, India is home to third 
largest population however with global prevalence of $0.3 \%$ only $^{1}$

The national plan for control of AIDS in India in NACO-.

It was launched in 1992 earlier as national aids control programme -(NACP-1)- where emphasis was on HIV surveillance in targeted group and prevention of high-risk activities, and screening of blood and blood products.

NACP-2 IN 1999- Marked the utilization of ART in diagnosed cases of HIV.NACP-3 in 2007-focused on expansion of support and access to treatment programme. $^{2}$

As per 2017 there are total of 21.40 lakh PLHIV cases in India and $50 \%$ of which reside in 4 states of India - Maharashtra, Andhra Pradesh, Tamilnadu and Karnataka. $^{3}$

\section{Aims and objectives: -}

AIM: -

To study the clinical manifestation of renal involvement of HIV patients and its correlation with virologic load and CD4 Tcell count, with correlation with cystatin $-\mathrm{c}$ as early biomarker of renal involvement in HIV patients.

\section{Objective: -}

To study the role of HIV infection to cause renal manifestation.

To study the correlation between the virologic load and immune status (CD4 T cell count) and renal manifestation of HIV patient on HAART.

To study the use of urinary CYSTATIN $-\mathrm{C}$ as an early bio marker for predicting the renal involvement in HIV patients.

Patients with HIV/AIDS satisfying inclusion and exclusion criteria from august 2019- august 2020.

Sample size: 75 patients.

\section{INCLUSION CRITERIA}

Patients who are HIV positive aged $>18$ years and admitted in Department of GeneralMedicine.

Criteria for renal involvement. Significant proteinuria $->1+$ on dipstick, Progressive decline in renal function.

USG indicating of renal abnormality (large kidney or echogenic kidneys)

\section{EXCLUSION CRITERIA}

History of concomitant hypertension, diabetes mellitus Patient with history of nephrotoxic drug abuse.

Patient diagnosed or documented with any form of auto immune renal disease Patient refusal or inability to provide informed consent

\section{METHODLOGY:}

Sample of 75 cases who attended Dr DY Patil medical college and hospital, DY Patil Vidyapeeth, Pimpri, Pune during the study period were selected. All procedures and interventions have been established only after obtaining adequate / appropriate consent in a prescribed form. Ethical 
clearance has been obtained from the Ethical clearance committee in a prescribed certificate. Upon enrollment in the study, written consent was obtained and duly signed by the patients in a prescribed format.

\section{RESULTS}

In the present study, 75 HIV patients were recruited whose mean age was $39.6 \pm 10$ years (Figure1). Of the 75 positive cases, $52 \%(n=39)$ were males and $48 \%$ were females $(n=36)$. The mean age of females was $36.8 \pm 9.8$ years and males were $42.2 \pm 9.6$ years.

These patients were given different combinations of ART regimen like TLE regimen,

\section{RALTEGRAVIR+DALTEGRAVIR/RITO}

NAVIR etc. The mean duration of ART regimen was $10.8 \pm 6.8$ years. Biochemical Parameters like Hemoglobin count $(\mathrm{Hb})$, WBC, Platelets, Serum creatinine, Blood Urea, $\mathrm{Na}+, \mathrm{K}+, \mathrm{Cl}-$, TSB, SGOT, SGPT, ALT, Total Protein, Serum Albumin, Spot UPCR, 24hr-urinary Protein, CD4 count on recruitment and after six months and urinary cystatin- $\mathrm{C}$ were analyzed to see the effect of the regimen duration on these parameter.

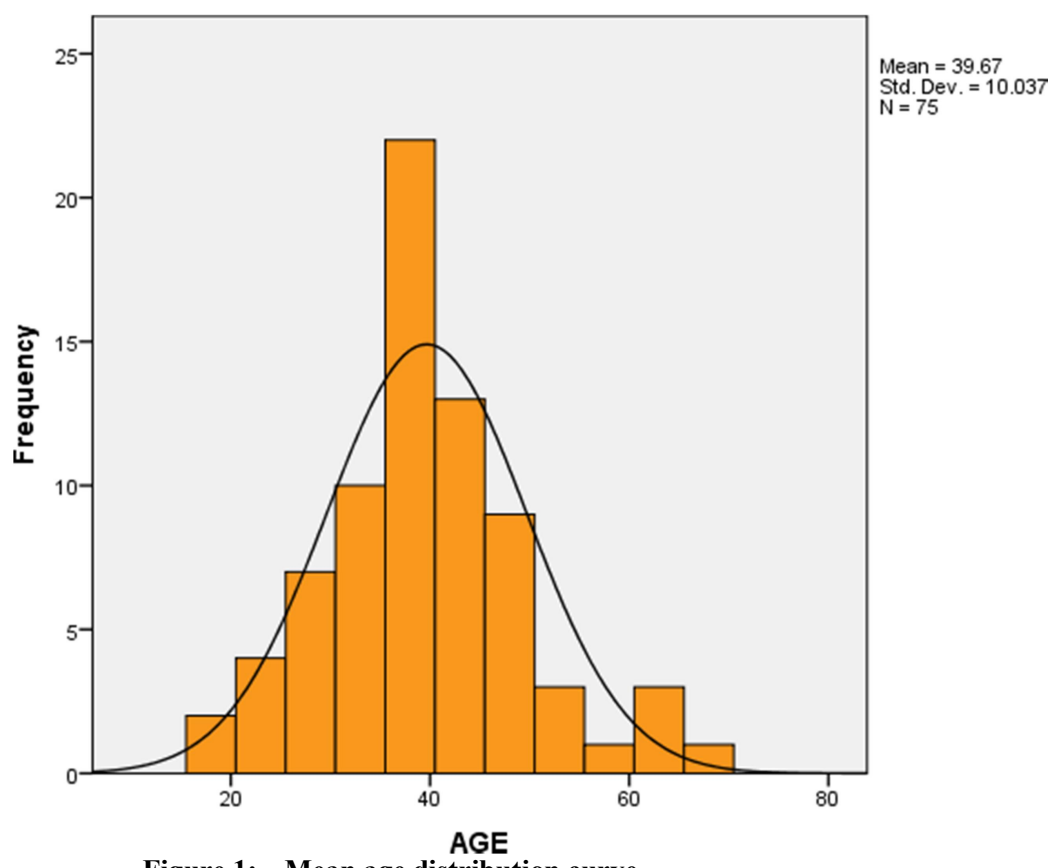

Figure 1: Mean age distribution curve

Table 1: frequency distribution table as per gender in study population

\begin{tabular}{|c|c|c|}
\hline Gender & Frequency & Percentage (\%) \\
\hline Female & 36 & 48 \\
\hline Male & 39 & 52 \\
\hline Total & 75 & 100 \\
\hline
\end{tabular}

Table 2: age and gender wise distribution chart among study population 


\begin{tabular}{|c|c|c|c|}
\hline \multirow{2}{*}{ Age group } & \multicolumn{2}{|c|}{ GENDER } & \multirow{2}{*}{ Total } \\
\cline { 2 - 3 } & Female (\%) & Male (\%) & 2 \\
$0-20$ & $1(0.75)$ & $1(0.75)$ & 43 \\
$41-40$ & $26(34.6)$ & $17(22.6)$ & 26 \\
$60-80$ & $8(10.6)$ & $18(24)$ & 4 \\
Total & $1(0.75)$ & $3(4)$ & 75 \\
\hline
\end{tabular}

Table 3: Different HAART regimens in study population

\begin{tabular}{|c|c|c|}
\hline & Frequency & Percent \\
\hline TLE & 39 & 52 \\
\hline RDRi & 23 & 30.6 \\
\hline RLoRi & 11 & 14.6 \\
\hline TLRLoRi & 1 & 1.4 \\
\hline ZLN & 1 & 1.4 \\
\hline Total & 75 & 100 \\
\hline
\end{tabular}

Table 4: Prevalence of renal parenchymal changes in study population

\begin{tabular}{|c|c|c|}
\hline & Frequency & Percent \\
\hline B/L NORMAL SIZED KIDNEYS & 58 & 77.2 \\
\hline B/L GRADE 1 RPD CHANGES & 13 & 17.4 \\
\hline B/L GRADE 2 INCREASED ECHOTEXTURE & 3 & 4 \\
NORMAL SIZE & & \\
\hline B/L GRADE 3 RPD CHANGES & 1 & 1.4 \\
\hline Total & 75 & 100 \\
\hline
\end{tabular}

Table 5: s. creatinine distribution in study population

\begin{tabular}{|c|c|c|}
\hline \multicolumn{3}{|c|}{ Serum Creatinine Groups } \\
\hline$<1$ & Frequency & Percent (\%) \\
\hline $1.0-2$ & 3 & 4 \\
\hline $2.1-3$ & 55 & 73.4 \\
\hline $3.1-4$ & 14 & 18.6 \\
\hline Total & 3 & 4 \\
\hline
\end{tabular}

The distribution of kidney size and changes in the architecture in the study population

Table 6: Distribution of 24 hour urinary protein in study population

\begin{tabular}{|c|c|c|}
\hline \multicolumn{3}{|c|}{ 24hr Urinary Protein } \\
\hline & Frequency & Percent (\%) \\
\hline$<1$ & 51 & 68 \\
\hline $1.0-2$ & 7 & 9.4 \\
\hline $2.1-3$ & 12 & 16 \\
\hline $3.1-4$ & 5 & 6.6 \\
\hline Total & 75 & 100 \\
\hline
\end{tabular}

Dipstick proteinuria

\begin{tabular}{|c|c|c|c|c|}
\hline \multicolumn{7}{c}{ Table 7: dipstick proteinuria prevalence in study population } \\
\hline Proteinuria - & Mild (+) & Moderate $(++)$ & $\begin{array}{c}\text { Gross } \\
(+++++++)\end{array}$ & No proteinuria \\
\hline No of patients & 37 & 14 & 16 & 8 \\
\hline $\begin{array}{c}\text { Percentage } \\
(\%)\end{array}$ & 49.3 & 18.6 & 21.3 & 10.6 \\
\hline
\end{tabular}

Measure of dipstick proteinuria with CD4+ T-cell count at time of diagnosis 
Table 8: dipstick proteinuria in correlation with CD4 T -cell count

\begin{tabular}{|c|c|c|c|c|c|}
\hline $\begin{array}{c}\text { CD4+ T- CELL } \\
\text { COUNT/ micro L }\end{array}$ & $<\mathbf{1 0 0}$ & $\mathbf{1 0 0 - 2 5 0}$ & $\mathbf{2 5 0 - 4 0 0}$ & $\mathbf{4 0 0 - 5 5 0}$ & $>\mathbf{5 5 0}$ \\
\hline Nil proteinuria & $\mathbf{2}$ & $\mathbf{4}$ & $\mathbf{1}$ & $\mathbf{1}$ & - \\
\hline Mild (+) & $\mathbf{5}$ & $\mathbf{1 7}$ & $\mathbf{4}$ & $\mathbf{5}$ & $\mathbf{6}$ \\
\hline Moderate (++) & $\mathbf{3}$ & $\mathbf{6}$ & $\mathbf{4}$ & $\mathbf{1}$ & - \\
\hline $\begin{array}{c}\text { Severe/gross } \\
(+++/++++)\end{array}$ & $\mathbf{9}$ & $\mathbf{3}$ & 4 & - & - \\
\hline & 19 & $\mathbf{3 0}$ & 13 & $\mathbf{6}$ & $\mathbf{6}$ \\
\hline
\end{tabular}

The effect of continuous use of HAART therapy on CD4 T -CELL count of thepatients.

The correlation studies within different parameters to see the test of significance with pearson $R$ value analysis

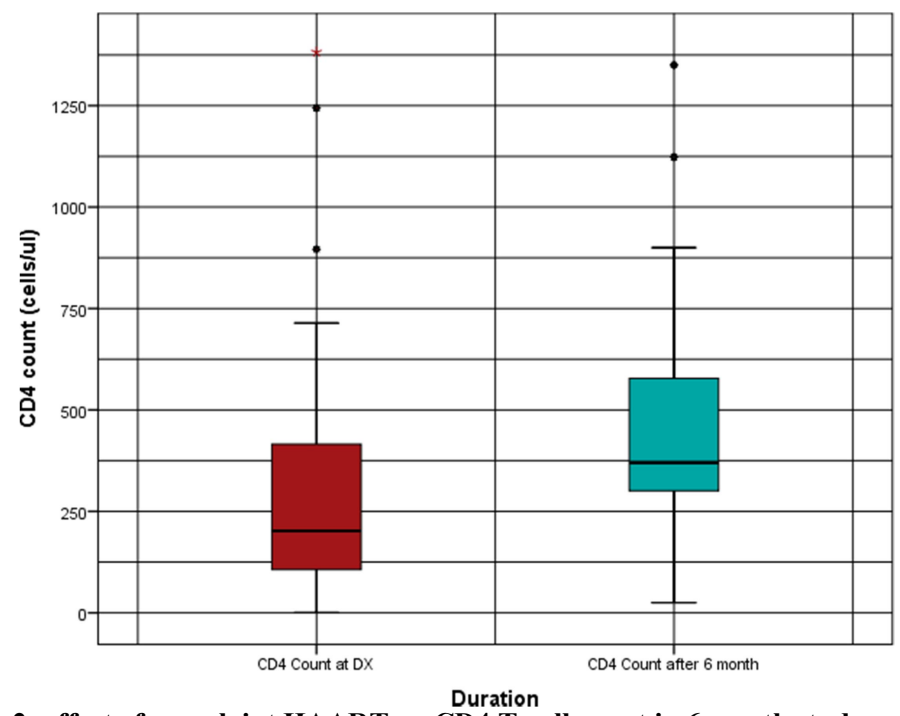

Figure 2: effect of complaint HAART on CD4 T-cell count in 6 month study period

Table 9: Pearson correlation values between different variables of study population

\begin{tabular}{|c|c|c|}
\hline & Pearson's R value & p Value \\
\hline $\begin{array}{c}\text { CD4 at Diagnosis vs Urinary } \\
\text { Cystatin-C }\end{array}$ & -0.32 & $0.005 *$ \\
\hline $\begin{array}{c}\text { Blood Urea vs Urinary Cystatin- } \\
\text { C }\end{array}$ & +0.55 & 0.0001* \\
\hline $\begin{array}{c}\text { Serum Creatinine vs Urinary } \\
\text { Cystatin-C }\end{array}$ & +0.48 & $0.0001 *$ \\
\hline $\begin{array}{c}\text { Duration of Therapy vs Urinary } \\
\text { Cystatin-C }\end{array}$ & +0.32 & $0.005 *$ \\
\hline $\begin{array}{c}\text { Spot Upcr vs Urinary Cystatin- } \\
\text { C }\end{array}$ & +0.70 & $0.0001 *$ \\
\hline $\begin{array}{c}\text { 24hrUrinary Protein vs Urinary } \\
\text { Cystatin-C }\end{array}$ & +0.71 & $0.0001 *$ \\
\hline Spot Upcr vs CD4 at Diagnosis & -0.23 & $0.04 *$ \\
\hline $\begin{array}{l}\text { 24hrUrinary Protein vs CD4 at } \\
\text { Diagnosis }\end{array}$ & -0.26 & $0.03 *$ \\
\hline
\end{tabular}

The following data was plotted to see the test of association between the variables 


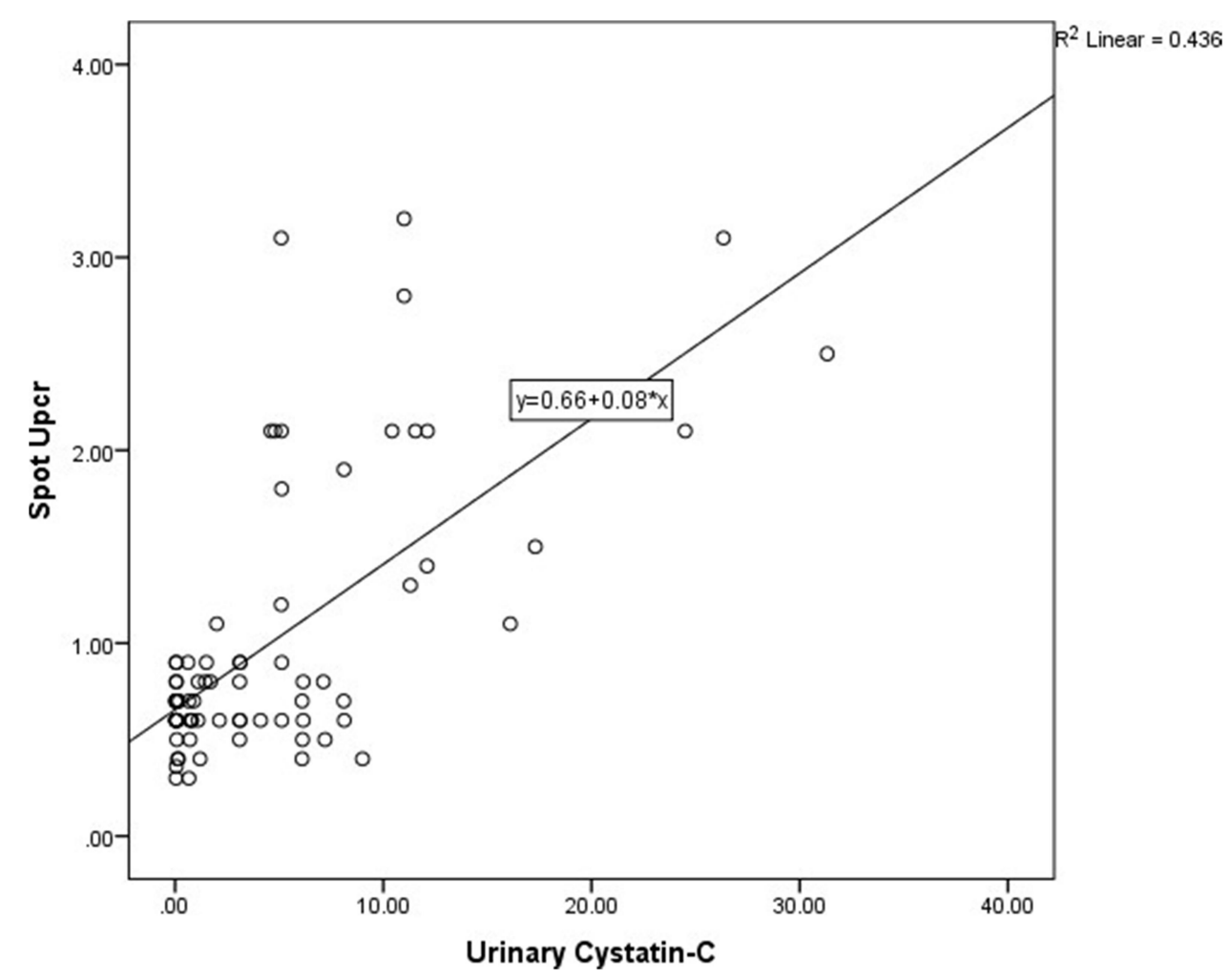

Figure 3: Pearson correlation graph between spot Uper and urinary cystatin-c

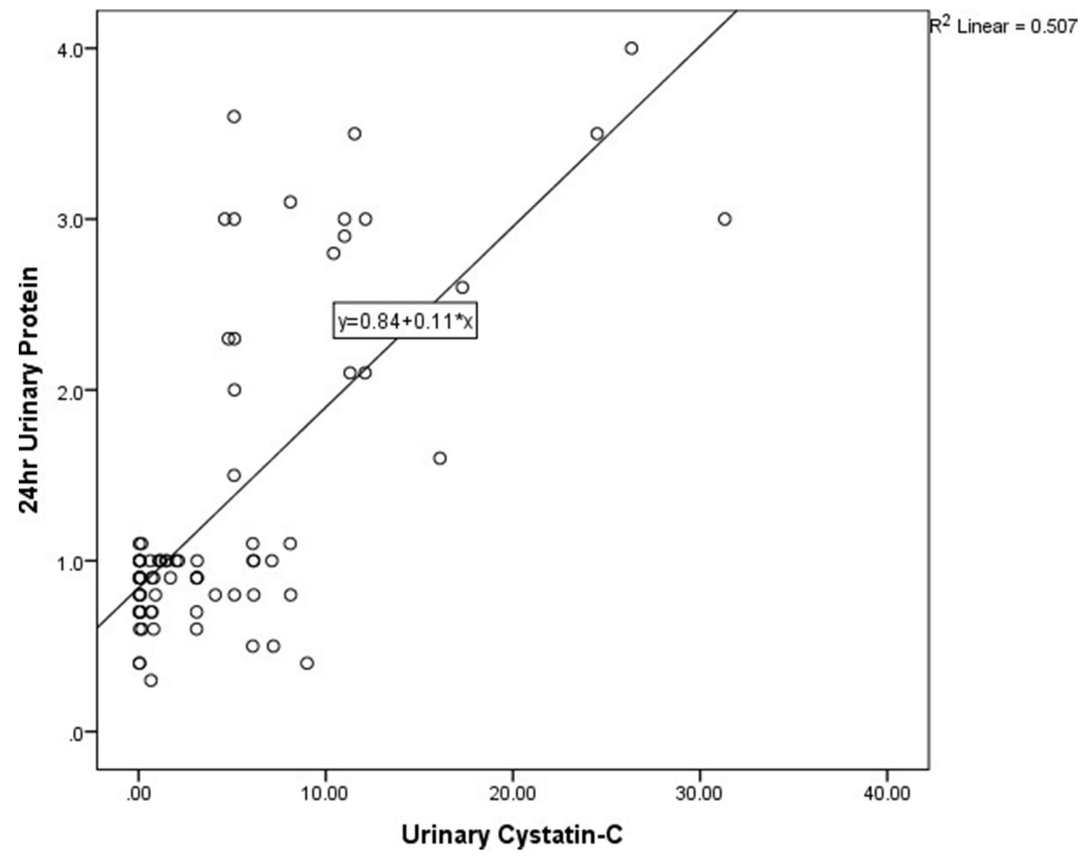

Figure 4: Pearsons correlation graph between $24 \mathrm{hr}$ urinary protein and urinary cystatin-c 


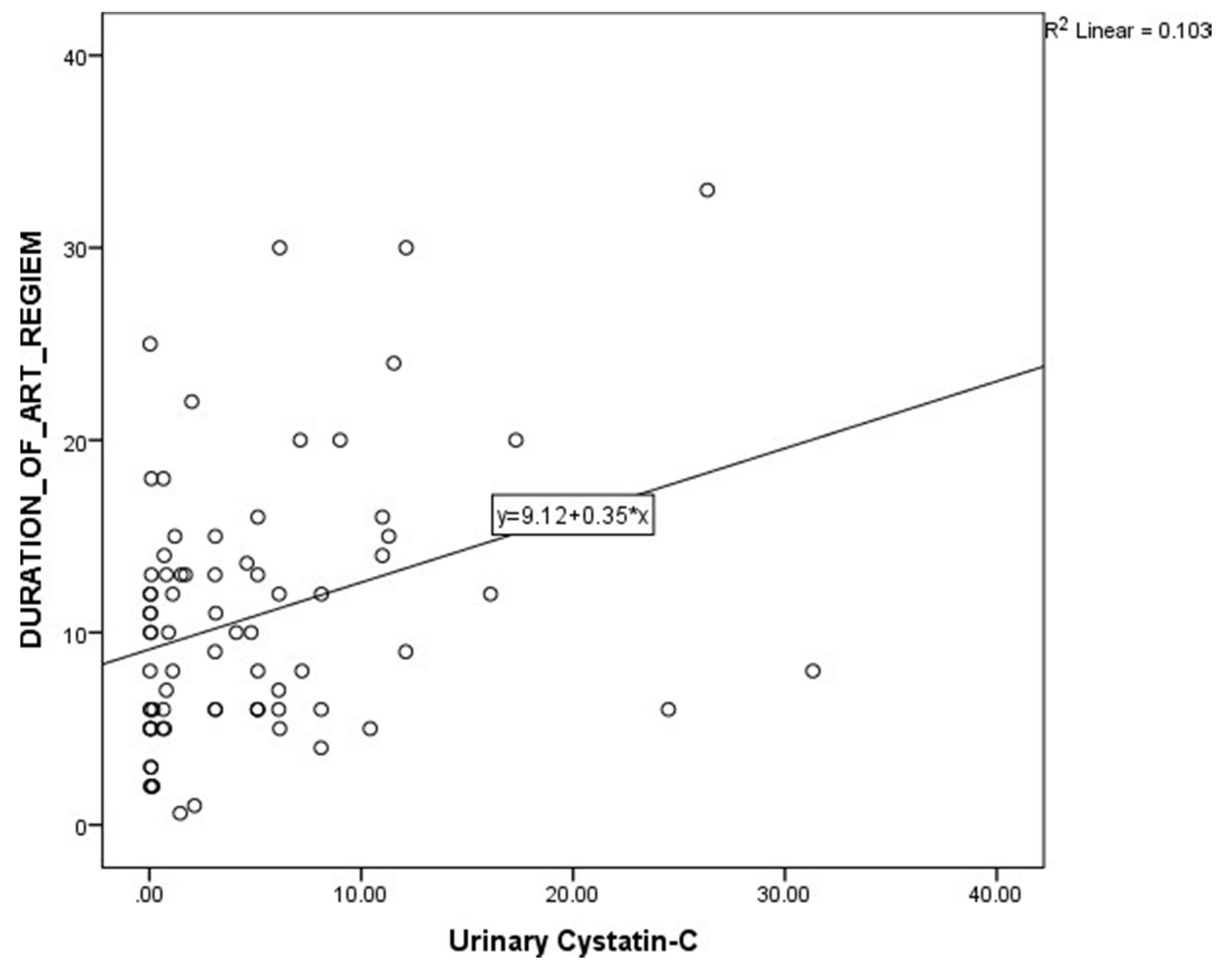

Figure 5: Pearsons correlation graph between duration of ART Regimen and urinary cystatin -c

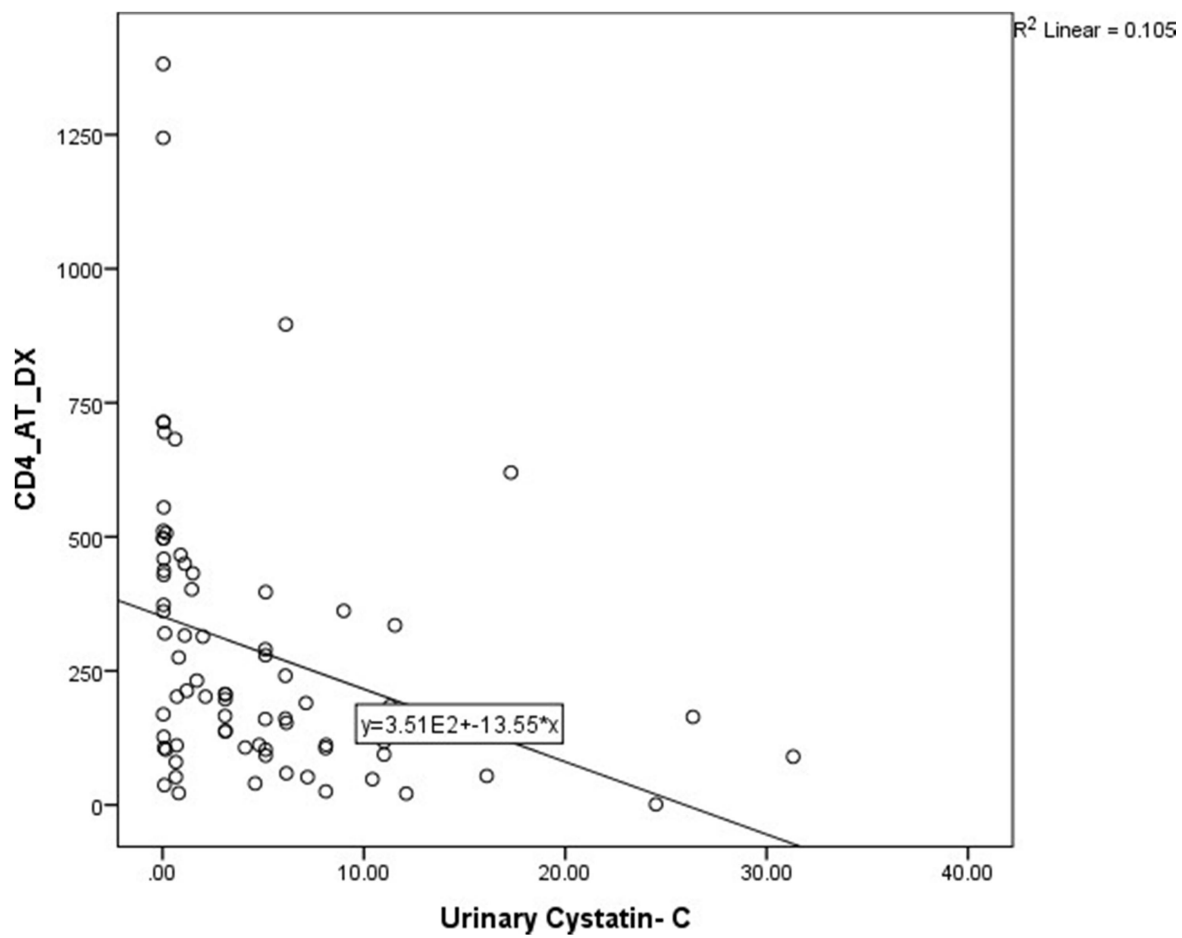

Figure 6: Pearsons correlation graph between CD4 T -cells at time of diagnosis and urinary cystatin -c 


\section{DISCUSSION}

The prevalence of dipstick-positive proteinuria in HIV-seropositive patients was high $(38 \%)$ and bears no relation to duration of HIV, CD4, HAART therapy and serum creatinine levels Chronic interstitial nephritis, either in isolation or superimposed on another glomerular lesion, was very common (71\%). Mesangioproliferative glomerulonephritis was the most common glomerular lesion like in other Indian studies. The absence of HIVAN in our HIV patients with proteinuria was a characteristic feature as per Wali et al, ${ }^{5}$ Nephropathies in HIV patients. however, the prevalence of dipstick is different in different studies within the Indian subset of population.

Biggs et $a l^{6}$ to evaluate the prevalence and spectrum of the changes seen on renal biopsy of patients with HIVAN, 27 cases were enrolled with male 23 and female 413 patients were subjected to renal biopsy showing glomerular disease in 55.5 $\%(5 / 13)$ showing FSGS vs tubule interstitial disease of $40 \%$.this study has cast doubt on assumption that renal biopsy manifestations are absent in Indian patients as all 13 patients showed a spectrum of renal involvement in HIVAN.

In the following study of 75 people suffering from HIV infection, on ART regimen The average hemoglobin was
$10.97 \mathrm{gm} / \mathrm{dl}+\ldots 1.23$, the hb values were lower in patient with low cd4 $\mathrm{T}$-cell count that the people with normal count.

The average wbc count 7364.3cell /microL+_6872.6 and average platelet count was $1.81+[0,2$, indicating no significance variability from normal count in population irrespective of duration and type of ART used.

There was near equal prevalence number of male and female population enrolled in the study (52\% vs $48 \%)$ respectively .t the mean age of females was $36.8 \pm 9.8$ years and males were $42.2 \pm 9.6$ years. The mean duration of use of HAART is 10.8 years in my study population with the maximum duration of 33 years and min of 1 year at the time of enrollment. the most common regimen used by the study population is TLE regimen (52\%) flowed by raltegravir; dolutegravir,+ritonavir/lopinavir in $30.6 \%$ and only 1 each patient was on $\mathrm{TL}+$ raltegravir, lopinavir/ritonavir and on old ZLN REGIMEN. most of the female population in study group were house wife, whereas the male belong to odd jobs involving migration from homes and belonging to low socio economic class. The age wise distribution of the study population reveals that among males and females the max population under study belonged to age group 21-40 years (22.6\% and $34.6 \%$ ) respectively indicating that 
about $57.2 \%$ population in study in between 21-40 years, which represents highly sexually active group which is slightly higher than the prevalence study found in HIV associated renal disease - a pilot study in north India by Vijay Gupta et al.

In this study the 2 other parameters were selected to assess the correlation of proteinuria ie -spot U PCR and 24 - hour urinary protein and the renal involvement was assessed by urinary level of cystatin c. Urine cystatin $\mathrm{C}$ - as a marker of tubular dysfunction. ${ }^{7-9}$

- Cystatin C is rapidly reabsorbed and degraded in renal tubular cells. In cases of tubular dysfunction, this is impaired and cystatin $\mathrm{C}$ is excreted as such in urine. The correlation was assessed with the help of Pearson correlation analysis and revealed a strong correlation between spot $\mathrm{U}$ pcr and cystatin $-c($ Pearson $R$ value of 0.7 and $p$ value 0.0001 ) and $24 \mathrm{hr}$ urinary protein and cystatin $-c$ (pearson $r$ value of +0.71 and $p$ value 0.0001) .histologically FSGS is the most common glomerular lesion in HIVAN and tubular dysfunction in the form of micro cystic tubular dilation, interstitial infiltrates and found in $60 \%$ cases , and urinary cystatin $-\mathrm{c}$ is essential a marker of tubular dysfunction presence of mild to moderate proteinuria $(>1+$ proteinuria $)$ in $67.9 \%$ indicated the renal tubular dysfunction appears much earlier than actual histological picture of FSGS in HIVAN , similar to findings The spectrum of renal histology seen in HIV with outcomes, prognostic indicators and clinical correlations. ${ }^{10}$

\section{CONCLUSION}

Dipstick proteinuria is the most effective measure for screening of the patients for renal manifestations in patients with HIV the significant proteinuria with $>1+$ on dipstick examination in patient with all other causes excluded (hypertension, diabetes mellitus) should always warrant for further investigation.

24 hour urinary and $>3 \mathrm{gm} / \mathrm{dl}$ spot Upcr $>3.5 \mathrm{gm} / \mathrm{dl}$ were more associated with HIV AN.

The low CD4+T -cells is associated with the early onset of renal manifestation with most values below $<200$ cells /microL , and poor adherence or lack of use of HAART, as studies have revealed that the HIV virus stimulates the PODOCYTES to differentiate and podocytopathy is the hallmark of HIVAN and cause of proteinuria

$7.60 \%$ of patients with HIVAN has tubular dysfunction without any obvious glomerular disease, hence urinary cystatin c which is marker of tubular dysfunction is early marker of renal disease in HIVAN 
patients even before the onset of nephrotic proteinuria.

\section{Conflict of Interest}

None

\section{Funding Support}

Nil

\section{REFERENCES}

[1] Carr JK, Avila M, Gomez Carrillo M, Salomon H, Hierholzer J, Watanaveeradej V, Pando MA, Negrete M Russell KL, Sanchez J, Birx DL, Andrade R, Vinoles J, McCutchan FE. Diverse BF recombinants have spread widely since the introduction of HIV-1 into South America. AIDS 2001;15:F41-7

[2] Alexaki A, Liu Y, Wigdahl B. Cellular reservoirs of HIV-1 and their role in viral persistence. Curr HIV Res 2008;6:388- 400

[3] Bangham CR. CTL quality and the control of human retroviral infections. Eur JImmunol 2009;39:1700-12.

[4] Gupta SK, Eustace JA, Winston JA, et al. Guidelines for the management of chronic kidney disease in HIV-infected patients: recommendations of the HIV Medicine Association of the Infectious Diseases Society of America. Clin Infect Dis 2005;40(11):1559-85.

[5] Wali, R. K. et al. (1998). HIV-1associated nephropathy and response to highly- active antiretroviral therapy. Lancet 352, 783-784.

[6] Briggs WA, Tanawattanacharoen S, Choi MJ, et al. Clinicopathologic correlates of prednisone treatment of human immunodeficiency virusassociated nephropathy. American Journal of Kidney Diseases 1996;28:618.

[7] Watterson MK, Detwiler RK, Bolin JP. Clinical response toprolonged corticosteroids in a patient with human immunodeficiency virus-associated nephropathy. American Journal of Kidney Diseases 1997;29:624.

[8] Smith MC, Austen JL, Carey JT, et al. Prednisone improves renal function and proteinuria in human immunodeficiency virus-associated nephropathy. Ameriacn Journal of Medicine 1996;101:41.

[9] Bhagani S, Sweny P, Brook G: Guidelines for kidney transplantation in patients with HIV disease. HIV Medicine 2006 ; 7:133-139.

[10] Casanova S, Mazzucco G, Barbiano $\mathrm{DB}$, et al: Pattern of glomerular involvement in human immunodeficiency virus- infected patients: An Italian study. American Journal of Kidney Diseases 1995;26: 446-453. 